\title{
HAEMATOLOGICAL STUDIES IN ADOLESCENT BREEDING COCKS
}

\author{
I. KRÁL, P. SUCHÝ
}

Department of Nutrition, Dietetics and Hygiene of Plant Products, Faculty of Veterinary Hygiene and Ecology, University of Veterinary and Pharmaceutical Sciences, Brno, Czech Republic

\author{
Received September 28, 1999 \\ Accepted July 27, 2000
}

Abstract

Král I., P. Suchý: Haematological Studies in Adolescent Breeding Cocks. Acta Vet. Brno 2000, 69: 189-194.

The objective of the study was to point out several significant changes in haematological values of male poultry occurring during sexual maturation and development of spermiogenesis using chickens (Gallus gallus domesticus L.) as a model species. The investigations were carried out in a set of 50 clinically normal breeding cockerels of the paternal line RIR-05 and covered the age span of 10 through 35 weeks. Blood samples collected at 5-week intervals from vena basilica were tested for total erythrocyte count (Er), packed cell volume (PCV), haemoglobin content $(\mathrm{Hb})$, mean corpuscular haemoglobin concentration $(\mathrm{MCHC})$, mean corpuscular haemoglobin content $(\mathrm{MCH})$, mean erythrocytic volume (MCV), and total leukocyte (Le), basophil (Ba), eosinophil (Eo), neutrophil (Ne), lymphocyte (Ly), and monocyte (Mo) counts. Changes in the erythrocytic component observed during the investigation period included highly significant $(P \leq 0.01)$ increases in Er from 1,793 to 3,484 T $\cdot 1^{-1}$, PCV from 0.243 to $0.4351 \cdot 1^{-1}$, and $\mathrm{Hb}$ from 69.94 to $136.57 \mathrm{~g} \cdot 1^{-}$ 1 . No significant changes were demonstrated for $\mathrm{MCHC}, \mathrm{MCH}$, and $\mathrm{MCV}$ in which mean values ranged from 26.17 to $31.531 \cdot 1^{-1}$, from 36.39 to $44.20 \mathrm{pg}$, and from 125.61 to $157.86 \mathrm{fl}$, respectively. A reverse tendency was observed in the leukocytic component. Le decreased highly significantly $(P \leq 0.01)$ from 20.270 to $12.788 \mathrm{G} \cdot \mathrm{l}^{-1}$. For this change, highly significant decreases in Ba from 0.138 to $0.065 \mathrm{G} .1^{-1}$, Eo from $0.0-104$ to $0.063 \mathrm{G} \cdot \mathrm{l}^{-1}$, and mostly Ly from 11.502 to $3.784 \mathrm{~g} \cdot \mathrm{l}^{-1}$ $(P \leq 0.01)$ and Mo from 0.104 to $0.063 \mathrm{G} \cdot 1^{-1}$ were responsible. Ne remained fairly constant varying within a narrow range of 7.742 to $8.626 \mathrm{G} \cdot \mathrm{I}^{-1}$. The paper provides new comprehensive information on haematological changes occurring during sexual maturation of male breeding chickens up to the onset of reproductive activity.

Domestic chicken, red blood cells, white blood cells

Haematological examinations provide valuable information on the metabolic profile, support objective assessment of the state of health, and are often helpful in the revelation of health disorders already at the preclinical stage. Although widely used in large animal medicine, they have not yet found the place they deserve in avian medicine.

Interpretation and sensible utilisation of results of haematological examinations are often limited by lack of physiological data relevant to the individual avian species, breeding lines, production types, sexual maturation, nutrition, etc.

Haematological values are a very important indicator of the state of health (Jantošovič 1967). Haematological studies in poultry were carried out by a number of authors, such as Beuving et al. (1993) and McFarlane and Curtis (1989). Results of studies in hens, chicken broilers, and quails were published by Jeřábek et al. (1993), Straková et al. (1993), and Straková et al. (1994), respectively.

This study was done to contribute to the current knowledge on avian haematology, or, more specifically, to describe some changes in haematological indicators occurring during the period of sexual maturation of male chickens. The elementary paper on this topic, pointing out significant increases in haemoglobin content, erythrocyte count, and PCV, a relatively narrow range of variations in mean corpuscular haemoglobin concentration

Address for correspondence:

MVDr. Ivan Král

Departient of Nutrition, Dietetics, and Hygiene of Plant Products

Veterinary and Pharmaceutical Sciences

Phone \& fax: 00420541562545

Palackého 1-3, 61242 Brno, Czech Republic 
(MCHC), mean haemoglobin content $(\mathrm{MCH})$, and mean erythrocytic volume (MCV), and absence of age effects on the leukocytic component, was published by Suchý et al. (1989). Similarly, Straková et al. (1996) reported a marked increase in Hb, Er, and PCV in maturating male breeder turkeys. An increase in PCV during this period in male turkeys was described also by Cecil and Bakst (1993).

\section{Materials and Methods}

Fifty cockerels of the paternal line RIR 05, purchased at the age of 9 weeks from INTAGRA, Žabčice, were housed in deep litter pens and fed ad libitum with feed mixtures containing 153.5 crude protein and $11.8 \mathrm{MJ}$ ME from the $10^{\text {th }}$ to the $18^{\text {th }}$ week of age and 185.3 crude protein and $12.4 \mathrm{MJ}$ ME from the $19^{\text {th }}$ week of age.

Ambient temperature, lighting and other environmental conditions fully met the requirements laid down in the technological instructions for breeding poultry. Mean live weights of the birds at the age of 10, 15, 20, 25, 30, and 35 weeks were $0.89,2.01,2.52,3.14,2.84$, and $3.34 \mathrm{~kg}$, respectively.

Haematological values were determined in the period of sexual maturation from the $10^{\text {th }}$ to the $25^{\text {th }}$ week of age and in the period of sexual maturity in the $25^{\text {th }}$ and $30^{\text {th }}$ weeks of age using the methods described by Hrubiško et al. (1981).

Blood samples were collected by puncture of $v$. basilica usually around $08.00 \mathrm{~h}$ at 5 -week intervals at the age of $10,15,20,25,30$, and 35 weeks. Total erythrocyte and leukocyte counts were determined using the haemocytometric method and the Natt-Herrick diluting solution. Hb was determined photometrically at $540 \mathrm{~nm}$ using the Drabkin solution and PCV by the capillary micromethod of Janetzki. Complementary indexes of the erythrocytic component, including $\mathrm{MCHC}, \mathrm{MVH}$, and $\mathrm{MCV}$, were derived by calculation from the Er, $\mathrm{Hb}$, and PCV values. Basophilic (Ba), neutrophilic (Ne), and eosinophilic (Eo) granulocytes, monocytes (Mo), and lymphocytes (Ly) were enumerated in blood smears prepared and stained panoptically with May-Grünwald and Giemsa-Romanowski immediately after sampling.

The results were processed using Student's $t$-test (Venčikov and Venčikov 1977).

\section{Results}

The results of haematological examinations show significant changes occurring in the blood of breeding cocks during sexual maturation and at the onset of reproductive activity.

In the erythrocytic component, the changes included increases in total erythrocyte counts (Er), packed cell volume (PCV), and total haemoglobin content (Hb).

Er increased from the initial value of $1.793 \mathrm{~T} \cdot \mathrm{l}^{-1}$ at the age of 10 weeks to $3.484 \mathrm{~T} \cdot \mathrm{l}^{-1}$ at the age of 35 weeks. As can be seen in Table 1, all the between-week differences except that between weeks 25 and 30 were highly significant $(P \leq 0.01)$.

A similar tendency was observed for PCV which increased from the initial $0.2431 \cdot \mathrm{I}^{-1}$ in week 10 to $0.441 \cdot 1^{-1}$ in week 30 . All the between-week differences were highly significant $(P \leq 0.01)$.

The same, including the significance of differences, applied to $\mathrm{Hb}$. Its mean values increased from the initial $69.94 \mathrm{~g} \cdot \mathrm{l}^{-1}$ in week 10 to $136.57 \mathrm{~g} \cdot \mathrm{l}^{-1}$ in week 35 .

No significant changes were observed during the experimental period for $\mathrm{MCHC}, \mathrm{MCH}$, and MCV.

MCHC varied from 26.17 to $31.531 \cdot 1^{-1}$ and similar variations were observed for $\mathrm{MCH}$ and MCV which fluctuated between 36.39 and $44.20 \mathrm{pg}$ and 125.61 and $157.86 \mathrm{fl}$, respectively. (Table 1). Although some of the between-week differences for all the three values were significant $(P \leq 0.05)$ or highly significant $(P \leq 0.01)$, they cannot not be considered a phenomenon depending on age or sexual maturation.

Certain, but less marked, changes were also observed in the leukocytic component (Table 2). Le decreased from 20.270 (week 15) to $12.788 \mathrm{G} \cdot 1^{-1}$ (week 35), the decreases observed in week 20 (to $15.334 \mathrm{G}^{-\mathrm{l}^{-1}}$ ) and week 30 (to $13.410 \mathrm{G} \cdot 1^{-1}$ ) being highly significant (Table 2).

Ba decreased from 0.138 (week 10) to $0.065 \mathrm{G} \cdot \mathrm{l}^{-1}$ (week 35), the differences observed in week 30 and week 35 being significant $(P \leq 0.05)$ and highly significant $(P \leq 0.01)$, respectively. 
Table 1

Changes in the erythrocytic component in breeding cocks during the period of sexual maturation. Er - total erythrocyte count; $\mathrm{PCV}$ - packed cell volume; $\mathrm{Hb}$ - haemoglobin content; $\mathrm{MCHC}$ - mean corpuscular haemoglobin concentration; $\mathrm{MCH}$ - mean haemoglobin content; MCV - mean erythrocytic volume. $P$ : $P \leq 0.05$ (1.9840), $P \leq 0.01$ (2.6259)

\begin{tabular}{|c|c|c|c|c|c|c|c|c|c|c|}
\hline & $\mathbf{X}$ & $s_{n-1}$ & $\mathbf{s}_{\mathrm{x}}$ & $\mathbf{v}$ & $\mathrm{P}$ & $X$ & $s_{n-1}$ & $\mathbf{s}_{\mathrm{x}}$ & $\mathbf{v}$ & $\mathrm{P}$ \\
\hline Week & \multicolumn{5}{|c|}{$\operatorname{Er} .\left(T \cdot \mathbf{l}^{-1}\right)$} & \multicolumn{5}{|c|}{$\operatorname{MCHC}\left(I^{-1} \mathrm{I}^{-1}\right)$} \\
\hline \multirow{2}{*}{10.} & 1.793 & 0.290 & 0.041 & 16.17 & \multirow{2}{*}{$\begin{array}{c}* * \\
2.829\end{array}$} & 28.97 & 3.57 & 0.505 & 1232 & \multirow[b]{2}{*}{1.164} \\
\hline & \multirow[b]{2}{*}{2.025} & \multirow[b]{2}{*}{0.503} & \multirow[b]{2}{*}{0.071} & \multirow[b]{2}{*}{24.84} & & \multirow[b]{2}{*}{29.95} & \multirow[b]{2}{*}{4.769} & \multirow[b]{2}{*}{0.674} & \multirow[b]{2}{*}{15.92} & \\
\hline 15. & & & & & \multirow{2}{*}{$\begin{array}{c}* * \\
4.718 \\
\end{array}$} & & & & & \multirow{2}{*}{$\begin{array}{c}* * \\
5.211 \\
\end{array}$} \\
\hline \multirow[b]{2}{*}{20.} & \multirow[b]{2}{*}{2.443} & \multirow[b]{2}{*}{0.372} & \multirow[b]{2}{*}{0.053} & \multirow[b]{2}{*}{15.23} & & \multirow[b]{2}{*}{26.17} & \multirow[b]{2}{*}{1.896} & \multirow[b]{2}{*}{0.268} & \multirow[b]{2}{*}{7.24} & \\
\hline & & & & & $* *$ & & & & & $* *$ \\
\hline & & & & & 5.408 & & & & & 5.953 \\
\hline 25. & 2.880 & 0.433 & 0.061 & 15.03 & & 28.78 & 2.455 & 0.347 & 8.53 & \\
\hline & & & & & 0.416 & & & & & 0.639 \\
\hline 30. & 2.918 & 0.482 & 0.068 & 16.52 & $* *$ & 28.38 & 3.686 & 0.521 & 12.99 & $* *$ \\
\hline & & & & & 5.237 & & & & & 4.481 \\
\hline 35. & 3.484 & 0.594 & 0.084 & 17.05 & & 31.53 & 3.341 & 0.472 & 10.60 & \\
\hline Week & & & $\mathrm{CV}(\mathbf{l} \cdot \mathrm{l}$ & & & & & $\mathbf{C H}(\mathbf{p}$ & & \\
\hline 10. & 0.243 & 0.025 & 0.004 & 10.29 & $* *$ & 38.99 & 7.020 & 0.993 & 18.00 & \\
\hline & & & & & 4.066 & & & & & 1.257 \\
\hline 15. & 0.266 & 0.026 & 0.004 & 9.77 & $* *$ & 37.09 & 8.060 & 1.140 & 21.73 & \\
\hline & & & & & 12.021 & & & & & 0.525 \\
\hline 20. & 0.334 & 0.028 & 0.004 & 8.38 & $* *$ & 36.39 & 4.880 & 0.690 & 13.41 & $* *$ \\
\hline & & & & & 9.058 & & & & & 3.166 \\
\hline 25. & 0.392 & 0.037 & 0.005 & 9.44 & $* *$ & 39.50 & 4.944 & 0.699 & 12.52 & $* *$ \\
\hline & & & & & 5.194 & & & & & 3.047 \\
\hline 30. & 0.441 & 0.054 & 0.008 & 12.24 & & 44.20 & 9.720 & 1.375 & 21.99 & $*$ \\
\hline 35 & 0,435 & 0038 & 0005 & 874 & 0.636 & 3985 & 8184 & 1157 & 2054 & 2.421 \\
\hline Week & & & & & & & & & & \\
\hline Week & & & $\mathbf{l b}\left(\mathrm{g} \cdot \mathrm{l}^{-}\right.$ & & & & & {$[C V(f)$} & & \\
\hline 10. & 69.94 & 8.059 & 1.140 & 11.52 & $* *$ & 136.24 & 25.360 & 3.386 & 18.61 & \\
\hline & & & & & 4.257 & & & & & 2.235 \\
\hline 15. & 78.53 & 11.780 & 1.665 & 15.00 & $* *$ & 125.61 & 23.640 & 3.340 & 18.82 & $*$ \\
\hline & & & & & 4.124 & & & & & 3.292 \\
\hline 20. & 87.62 & 10.210 & 1.444 & 11.65 & $* *$ & 139.82 & 19.341 & 2.735 & 13.83 & \\
\hline & & & & & 11.108 & & & & & 1.256 \\
\hline 25. & 112.38 & 12.010 & 1.698 & 10.69 & $* *$ & 135.36 & 16.020 & 2.266 & 11.84 & $* *$ \\
\hline & & & & & 4.082 & & & & & 3.995 \\
\hline 30. & 123.72 & 15.550 & 2.199 & 12.57 & $* *$ & 157.86 & 36.460 & 5.156 & 23.10 & $*$ \\
\hline & & & & & 4.358 & & & & & 2.421 \\
\hline 35. & 136.57 & 13.890 & 1.964 & 10.17 & & 131.07 & 23.819 & 3.369 & 18.17 & \\
\hline
\end{tabular}


Table 2

Changes in the leukocytic component in breeding cocks during the period of sexual maturation. Le - total leukocyte count; $\mathrm{Ba}$ - basophile count; Eo - eosinophile count; $\mathrm{Ne}$ - neutrophile count; $\mathrm{Ly}$ - lymphocyte count;

Mo - monocyte count. $P: P \leq 0.05$ (1.9840), $P \leq 0.01$ (2.6259)

\begin{tabular}{|c|c|c|c|c|c|c|c|c|c|c|}
\hline & $\mathbf{X}$ & $s_{n-1}$ & $s_{x}$ & $\mathbf{v}$ & $\mathrm{P}$ & $\mathrm{X}$ & $s_{n-1}$ & $s_{x}$ & $\mathbf{v}$ & $\mathrm{P}$ \\
\hline Week & \multicolumn{5}{|c|}{$\operatorname{Le}\left(G \cdot I^{-1}\right)$} & \multicolumn{5}{|c|}{$\mathrm{Ne}\left(G \cdot \mathrm{I}^{-1}\right)$} \\
\hline \multirow{2}{*}{10.} & 20.114 & 5.202 & 0.736 & 25.86 & \multirow[b]{2}{*}{0.147} & 8.626 & 3.346 & 0.473 & 38.79 & \multirow[b]{2}{*}{0.103} \\
\hline & \multirow[b]{2}{*}{20.270} & \multirow[b]{2}{*}{5.398} & \multirow[b]{2}{*}{0.763} & \multirow[b]{2}{*}{26.63} & & \multirow[b]{2}{*}{8.562} & \multirow[b]{2}{*}{2.871} & \multirow[b]{2}{*}{0.406} & \multirow[b]{2}{*}{33.53} & \\
\hline 15. & & & & & \multirow{2}{*}{$\begin{array}{c}* * \\
4.694 \\
\end{array}$} & & & & & \multirow[b]{2}{*}{0.498} \\
\hline \multirow[b]{2}{*}{20.} & \multirow[b]{2}{*}{15.33} & \multirow[b]{2}{*}{5.130} & \multirow[b]{2}{*}{0.725} & \multirow[b]{2}{*}{33.46} & & \multirow[b]{2}{*}{8.227} & \multirow[b]{2}{*}{3.787} & \multirow[b]{2}{*}{0.536} & \multirow[b]{2}{*}{46.03} & \\
\hline & & & & & \multirow[b]{2}{*}{0.033} & & & & & \\
\hline & & & & & & & & & & 0.289 \\
\hline 25. & 15.36 & 3.800 & 0.537 & 24.74 & $* *$ & 8.049 & 2.153 & 0.304 & 26.75 & \\
\hline & & & & & 2.920 & & & & & 0.830 \\
\hline 30. & 13.41 & 2.809 & 0.397 & 20.94 & & 7.742 & 1.494 & 0.211 & 19.30 & \\
\hline 35. & 12.788 & 4.004 & 0.566 & 31.31 & 0.899 & 8.605 & 3.069 & 0.434 & 35.67 & 1.788 \\
\hline Week & & & $\mathbf{B a}\left(\mathbf{G} \cdot \mathbf{l}^{-}\right.$ & & & & & $y\left(G^{\prime}\right)^{-1}$ & & \\
\hline 10. & 0.138 & 0.119 & 0.017 & 86.23 & & 10.898 & 3.753 & 0.531 & 34.44 & \\
\hline & & & & & 0.798 & & & & & 0.817 \\
\hline 15. & 0.123 & 0.054 & 0.008 & 43.90 & & 11.502 & 3.642 & 0.515 & 31.66 & $* *$ \\
\hline & & & & & 0.390 & & & & & 8.044 \\
\hline 20. & 0.118 & 0.071 & 0.010 & 60.70 & & 6.832 & 1.897 & 0.268 & 27.77 & \\
\hline & & & & & 0.269 & & & & & 0.466 \\
\hline 25. & 0.122 & 0.075 & 0.011 & 61.48 & $* *$ & 7.036 & 2.448 & 0.346 & 34.79 & $* *$ \\
\hline & & & & & 2.206 & & & & & 3.736 \\
\hline 30. & 0.092 & 0.055 & 0.008 & 59.78 & $* *$ & 5.452 & 1.734 & 0.245 & 31.81 & $*$ \\
\hline 35. & 0065 & 0021 & 0003 & 3231 & 3.160 & 3784 & 1107 & 0.157 & 2025 & 5.732 \\
\hline Week & & & $\operatorname{Eo}\left(\mathbf{G} \cdot \mathrm{l}^{-}\right.$ & & & & & o ( G. I & & \\
\hline 10. & 0.104 & 0.054 & 0.008 & 51.92 & & 0.104 & 0.054 & 0.008 & 51.92 & \\
\hline & & & & & 0.224 & & & & & 2.704 \\
\hline 15. & 0.102 & 0.027 & 0.004 & 26.47 & $* *$ & 0.102 & 0.027 & 0.004 & 26.47 & $* *$ \\
\hline & & & & & 4.419 & & & & & 4.419 \\
\hline 20. & 0.077 & 0.025 & 0.004 & 32.47 & & 0.077 & 0.025 & 0.004 & 32.47 & \\
\hline & & & & & 1.525 & & & & & 1.525 \\
\hline 25. & 0.088 & 0.043 & 0.006 & 48.86 & $* *$ & 0.088 & 0.043 & 0.006 & 48.86 & $* *$ \\
\hline & & & & & 3.320 & & & & & 3.320 \\
\hline 30. & 0.067 & 0.014 & 0.002 & 20.89 & & 0.067 & 0.014 & 0.002 & 20.90 & \\
\hline 35. & & 0.020 & & & 1.109 & 0.063 & 0.020 & 0.003 & & 1.109 \\
\hline 35. & 0.063 & 0.020 & 0.003 & 31.75 & & 0.063 & 0.020 & 0.003 & 31.75 & \\
\hline
\end{tabular}


Eo decreased from 0.104 (week 10) to $0.063 \mathrm{G} \cdot \mathrm{l}^{-1}$ (week 35). Highly significant differences were observed in weeks 20 and 30 (Table 2).

Unlike Ba and Eo, Ne varied within a relatively narrow range of 7.742 to $8.626 \mathrm{G} \cdot \mathrm{l}^{-1}$. None of the between-week differences was significant (Table 2).

The most marked changes during the period of sexual maturation were observed in Ly. The initial count of $11.502 \mathrm{G} \cdot \mathrm{l}^{-1}$ (week 15) decreased to $3.784 \mathrm{G} \cdot \mathrm{l}^{-1}$ (week 35). Highly significant differences were observed in weeks 20,30 , and 35 (Table 2).

Unlike other leukocyte types, Mo fluctuated atypically within the range of 0.063 to 0.104 $\mathrm{G} \cdot \mathrm{1}^{-1}$. Although the differences between observed in weeks 15 and 30 were highly significant $(P \leq 0.01)$, they cannot be attributed to developmental changes occurring during the period of sexual maturation.

\section{Discussion}

The results of haematological studies in adolescent cocks demonstrate unambiguously that sexual maturation and the onset of reproductive activity were associated with significant physiological changes in the blood. The changes were characterised by intensive erythropoiesis apparent from increases in total erythrocyte counts, PCV, and haemoglobin content. Within the age span of 10 to 35 weeks, Er increased from 1.793 to $3.484 \mathrm{~T} \cdot \mathrm{l}^{-1}$, PCV from 0.243 to $0.4411 \cdot 1^{-1}$, and $\mathrm{Hb}$ from 69.94 to $136.57 \mathrm{~g} \cdot \mathrm{l}^{-1}$. The continuous highly significant $(P \leq 0.01)$ rise of the three haematological indicators reaching almost double values at the end of the experimental period can be regarded as a phenomenon characteristic for the period of the gonadal and spermiogenetic development.

Results of haematological studies in poultry were published by several authors, such as Beuving et al. (1986), or McFarlane and Curtis (1989), but the first to describe such changes in the blood of cocks was Suchý et al. (1989). Although the above studies were conducted in relatively small sets of birds, their conclusions are the same as those arrived at in our investigations. In comparison with other authors, our experimental period was prolonged from the $25^{\text {th }}$ to the $35^{\text {th }}$ week of age.

Our results indicate that the changes in haematological values continue up to the age of 35 weeks, i.e. to the onset of reproductive activity associated with intensive spermiogenesis. Our data probably apply also to males of other poultry species, because similar results were published also by Straková et al. (1994) for Japanese quails and Cecil and Bakst (1993) and Straková et al. (1996) for breeding turkeys.

Unlike the absence of changes in the leukocytic component reported by Suchý et al. (1989), our results indicate changes in leukocyte counts occurring during the period of sexual maturation and the onset of reproductive activity. This discrepancy may have been due to differences in group sizes and the fact that in our study the age span was extended from 25 to 35 weeks and that the most marked changes in leukopoiesis were observed during the last ten weeks. Thus, for the whole experimental period Le decreased from 20.114 to $12.788 \mathrm{G} \cdot \mathrm{l}^{-1}$, the differences being highly significant $(P \leq 0.01)$ in weeks 20 and 30 . Although $\mathrm{Ba}$ and Mo also decreased highly significantly $(P \leq 0.01)$ in weeks 20 and 30, mostly responsible for the change in Le were highly significant $(P \leq 0.01)$ decreases in Ly in weeks 20,30, and 35 .

Remarkably, Ne fluctuated within a relatively narrow range of $7.742-8.626 \mathrm{G} \cdot \mathrm{l}^{-1}$ throughout the experimental period.

It can be concluded that the results presented here throw light on some hitherto lesser known haematological changes occurring during the period of sexual maturation of and at the onset of reproductive activity in breeding cocks and thus extend the current knowledge of avian haematology. 


\section{Hematologie u plemenných kohoutů v období jejich pohlavního dospívání}

Cílem práce bylo upozornit na některé významné změny v krvi samců drůbeže, ke kterým dochází v průběhu jejich pohlavního dospívání a rozvoje spermiogeneze. Jako modelový druh byl vybrán kur domácí (Gallus gallus domesticus L.). Sledování probíhalo na souboru 50 klinicky zdravých plemenných kohoutů otcovské linie RIR - 05 v období od 10. do 35 . týdne jejich věku. Krev pro hematologická vyšetření byla odebírána v pětitýdenních intervalech punkcí vena basilica. $\mathrm{V}$ odebrané krvi byl sledován celkový počet erytrocytů $(\mathrm{Er})$, hematokritová hodnota $(\mathrm{Hk})$, obsah hemoglobinu $(\mathrm{Hb})$, průměrná koncentrace hemoglobinu v erytrocytech (MCHC), průměrný obsah hemoglobinu v erytrocytech $(\mathrm{MCH})$, průměrný objem erytrocytů (MCV), celkový počet leukocytů (Le) a zastoupení jednotlivých typů leukocytů, tj. bazofilních (Ba), eozinofilních (Eo) a neutrofilních $(\mathrm{Ne})$ granulocytů, dále lymfocytů (Ly) a monocytů (Mo). Ve sledovaném období dochází $\mathrm{k}$ vysoce průkaznému $(P \leq 0.01)$ zvýšení Er z $1.793 \mathrm{~T} \cdot \mathrm{l}^{-1}$ na $3.484 \mathrm{~T} \cdot \mathrm{l}^{-1}$, Hk z $0.2431 \cdot \mathrm{l}^{-1}$ na $0.4351 \cdot \mathrm{l}^{-1}$ a u Hb z $69.94 \mathrm{~g} \cdot \mathrm{l}^{-1}$ na $136.57 \mathrm{~g} \cdot \mathrm{l}^{-1}$. U MCHC, MCH a MCV tyto závislosti prokázány nebyly a stanovené průměrné hodnoty se pohybovaly v rozmezí u MCHC 26.17 - $31.531 \cdot 1^{-1}$ u MCH $36.39-44.20 \mathrm{pg}$ a u MCV od $125.61-157.86 \mathrm{fl}$.

Zcela opačná závislost byla pozorována u leukocytů, kdy v průběhu sledovaného období nastal jejich vysoce průkazný $(P \leq 0.01)$ pokles z $20.270 \mathrm{G} \cdot \mathrm{l}^{-1}$ na $12.788 \mathrm{G} \cdot \mathrm{l}^{-1}$. Tento pokles leukocytů byl dán vysoce průkazným poklesem Ba z $0.138 \mathrm{G} \cdot \mathrm{l}^{-1}$ na $0.065 \mathrm{G} \cdot \mathrm{l}^{-1}$, Eo z 0.104 $\mathrm{G} \cdot \mathrm{l}^{-1}$ na $0.063 \mathrm{G} \cdot \mathrm{l}^{-1}$ a především vysoce průkazným $(P \leq 0.01)$ poklesem Ly z $11.502 \mathrm{G} \cdot \mathrm{l}^{-1}$ na $3.784 \mathrm{G} \cdot \mathrm{l}^{-1}$ a Mo z $0.104 \mathrm{G} \cdot \mathrm{l}^{-1}$ na $0.063 \mathrm{G} \cdot \mathrm{l}^{-1}$. Za velmi stabilní lze pokládat počty $\mathrm{Ne}$, které se v období od 10. do 35. týdne věku kohoutů pohybovaly pouze v úzkém rozmezí od $7.742 \mathrm{G} \cdot \mathrm{l}^{-1}$ do $8.626 \mathrm{G} \cdot \mathrm{l}^{-1}$. Práce přináší nové komplexní vědecké poznatky o změnách v krevním obraze, ke kterým dochází v prủběhu pohlavního dospívání a nástupu reprodukčního období u plemenných kohoutů.

\section{Acknowledgment}

The results presented here were obtained within the research project "Effects of Mineral Nutrition on Metabolism, Development of Gonads, and Spermiogenesis in Male Poultry" supported by the Ministry of Agriculture of the Czech Republic (Project No. 6373/96).

\section{References}

BEUVING, G., JONES, R. B., BLOKHUIS, H. J. 1984: Adrenocortical and heterophil lymphocyte responses to challenge in hens showing short or long time tonic immobility reactions. Brit. Poult. Sci. 65: 495-501

CECIL, H. C., BAKST, M. R. 1993: Correlation of organ weights hematocrit and testosterone with sexual maturity of the male turkey. Poult. Sci. 70: 1252-1257

HRUBIŠKO, M. et al. 1981: Hematológia a transfúzológia.Vydavatelstvo Osveta, Martin, 493 p.

JANTOŠOVIČ, J. 1967: Zmeny v krvnom obraze u kurčiat při klasickom more. Folia veter. 8: 199-202

JEŘÁBEK, S., SUCHÝ, P., ILLEK, J., STRAKOVÁ, E., ZELENKA, J. 1993: Hematological and some biochemical parameters of blood of hens with damaged and integral shells. Živoč. Výr. 38: 145-151

McFARLANE, J. M., CURTIS, S. E. 1989: Multiple concurrent stressors in chicks. Effects on plasma corticosterone and heterophil lymphocyte ratio. Poult. Sci. 68: 522-527

SUCHÝ, P., JEŘÁBEK, S., STANEK, S., ZELENKA, J. 1989: Dynamic of Changes in the Blood Picture and Biochemical Indicators of Blood Plasma in Breeder Cocks during the Period of Sexual Maturation. Živoč. Výr. 34: $741-750$

STRAKOVÁ, E., SUCHÝ, P., KLECKER, D. 1998: Changes in hematological and biochemical characteristics of blood of broilers during fattening. Živoč. Výr. 38: 725-734

STRAKOVÁ, E., SUCHYY, P., KLECKER, D., ILLEK, J. 1994: Hematologické a biochemické ukazatele krve křepelky japonské $\mathrm{v}$ průběhu odchovu a snášky. Živoč. Výr. 39: 409-419

STRAKOVÁ, E., SUCHÝ, P., ILLEK, J. 1996: Variations of hematological indicators in breeding stags in the sexual maturation period. Živoč. Výr. 41: 199-203

VENČIKOV, A. I., VENČIKOV, V. A. 1977: Základní metody statistického zpracování dat ve fyziologii. AVICENUM, Praha, $160 \mathrm{p}$. 